\title{
MATERIAL MANAGEMENT: A SUSTAINABLE WAY TO REDUCE THE WASTAGE
}

\author{
Karm P. Balar ${ }^{1 *}$, Rushabh A. Shah ${ }^{2}$, Dr. Jayesh A. Shah ${ }^{3}$
}

\section{*Corresponding Author: -}

\begin{abstract}
: -
In today's world construction work are going at unexpected speed in all area like building, bridge, high-rise and so on. As we know there are two side of coin same way there are some disadvantages of this speedy construction which leads towards a wastage, like Material, Money, Time, and so on. One of the most important parts of wastage is due to Improper Material Management. If we not prepare good management technic of material management than it converts in to wastage. It shall be very hard to manage wastage rather than managing the material. So, if we want to manage the waste, we need to manage the material in Proper Way. For that first of all we need to find out the importance of Phases of Material Management and Crucial Factors which affects the material management.
\end{abstract}

Keywords: - material management, waste management, money. 


\title{
INTRODUCTION
}

Material management (MM) is a concept which is used in all construction work, from low budget to high budget business, \& also in construction sector. A big issue face now a day for any project was how to manage the material for construction work. Improper management of material impart a big effect on estimated time and cost of project which leads to time and cost overrun. As we know a huge quantity of material was used in bridge and high-rise building, so it was mostly required to manage the material at different phase for proper work and to reduce the wastage of material for ignorance of TOR and COR.

However, it should be underlined that Material management is not a tool which ensures success but rather a tool which helps to increase the probability of achieving success. The research in this master thesis focuses on the effect of material management on the project scheduling for bridge work \& high-rise building. Also, we discuss about its wastage and how its effect on time over run \& cost overrun for any project.

\section{Need of study}

Project finishing on time and the phase relevant to project are performed according to project schedule are consider the most important factor which are helpful for success of project. A Material Management (MM) is necessary for the project to complete the task as per time. There is a need of scientific approach considering causes of wastage of material due to lake of MM. such approach will provide the reason for the best possible way to overcome the wastage of material and also the reason for avoidable of the material management. Failure of material management was termed as wastage. And wastage of material was effect on cost of the project and duration of complatetion time of project. MM have become an issue widely discussed across industries. So many construction companies are aware about material management, but are still not using models and techniques aimed for managing different kind of material.

Hence this study is planned to develop a approach for need of material management and causes of wastage of material with help of relevant method which will help to management to understand the problem. The main purpose for prepare this study is to identify the factor affecting for the wastage of material, also reason for avoiding the MM for project and to identify their effect on complatetion time of project and cost factor of project.

\section{Material Management}

Materials constitute a major Cost component for any Industry. The total Cost of installed materials (or Value of Materials) may be $60 \%$ or more of the total Cost (Stukhart 2007, Bernold and Treseler 1991), even though the factory Cost may be a minor part of the total, probably less than $20-30 \%$. This is because the manufactured item must be stored, transported, and restored before it is put in place or "consumed" at the site. Materials management is a process for planning, executing and controlling field and office activities in construction. The goal of materials management is to insure that construction materials are available at their point of use when needed. Materials management is an important element in project management. Materials represent a major expense in construction, so minimizing procurement Costs improves opportunities for reducing the overall project Costs. Poor materials management can result in increased Costs during construction. If materials are purchased too early, capital may be held up and interest charges incurred on the excess inventory of materials. Materials may deteriorate during storage or get stolen unless special care is taken. Delays and extra expenses may be incurred if materials required for particular activities are unavailable. Ensuring a Timely flow of materials is an important concern of material management. Material Management require Purchase management, Inventory control, Material handling: Vendor selection, Make or buy decision, Negotiation, Costreduction techniques - Standardization, codification and variety reduction, waste management, Value analysis, Determination and description of material, quality acceptance, sampling plan.

Aim of material management To get

1. The Right quality

2. Right quantity of supplies

3. At the Right Time

4. At the Right place

5. For the Right Cost

\author{
Objective of material management \\ 1) Primary Objectives: \\ 1. Low Prices: \\ 2. Lower Inventories: \\ 3. Reduction in Real Cost: \\ 4. Regular Supply: \\ 5. Procurement of Quality Materials: \\ 6. Efficient handling of Materials: \\ 7. Enhancement of firm's goodwill: \\ 8. Locating and developing future Executives:
}



2) Secondary Objectives:
1. Reciprocity:
2. New Developments:
3. Make or Buy Decisions:
4. Standardisation:
5. Assistance to Production department:
6. Co-operation with other departments:
7. Conception of future outlook:

\section{Function of material management}

1. Material planning \& budgeting

2. Storage of materials

3. Inventory control

4. Material handling \& transportation

5. Disposal of scrap

6. Purchase analysis \& research

7. Material planning and programming

8. Purchasing and outsourcing

9. Inventory control

10. Storekeeping and warehousing

11. Codification

12. Standardization and evaluation of all products

13. Transportation and material handling

14. Inspection and quality control

15. Cost reduction through value analysis

16. Disposal of surplus / obsolete material

17. Distribution

\section{Phases in material management}

1. Material planning and forecasting

2. PRP (Purchasing, procuring, receiving)

3. Inventory planning \&management

4. Management the flow \& supply of material

5. Quality \& Cost control

6. Specification \& standardization of material

7. Coding and classification of material

8. Material handling

9. Distribution of material

10. Transportation

11. Waste management

12. Good supplier \& customer relationship

13. Efficient production scheduling

14. Selection of alternative material

The relationship of material management with other areas of management can be explained as follows:

(a) Materials and profitability:

The materials department can contribute effectively to corporate profits because this function results in a major portion of the cash Outflow in a business. Materials manager can substantially contribute in saving material Cost by effectively managing the materials.

The material manager can suggest the new alternatives to reduce the Cost or dependence on imports of materials. The import substitution also results in savings of valuable foreign exchange, thereby helping in the growth of the economy.

\section{(b) Material Management and Production department:}

Material department helps in a long way in providing uninterrupted supply of materials. Unless there is a close harmony and mutual trust between these two departments, the unrestricted flow of production cannot be maintained.

The materials department advises the production department promptly of any change in quality, quantity, increased rejection, thereby enabling any changes in scheduling to be carried out with minimum delay.

\section{(c) Material Management and Finance department:}

The relationship between the material and finance departments can be compared to the relationship between the examinee with an examiner. The finance department is concerned with providing finance for the materials purchased and it may find fault with the materials purchased.

It must be assured that the cash outflow in materials is properly planned by preparing a materials budget fixing economic order quantity, maximum, minimum and danger levels, so that, there is neither overstocking nor understocking. 
(d) Materials Management and Personnel department:

The personnel required in the materials department are recruited and selected by the personnel department. The materials department should not employ the unwanted or rejected people from the other departments.

Instead, the employees should be expert in handling various activities such as inviting tenders, preparing comparative statements, meeting the suppliers, drafting order for materials and taking up the follow up action.

\section{(e) Relationship between Material and Marketing department:}

Consumer is the king in the modern marketing scenario. The consumer must feel that the finished products purchased by him are of high quality and are durable. He expects that a right quality product is being purchased by him at the right price and right Time.

The success or failure of an organisation ultimately depends on the acceptance of products by the ultimate consumers. The material being the prime component plays a vital role in creating and maintaining the satisfied consumers.

\section{Principles of material management}

\section{Effective management \& supervision}

- Planning

- Organizing

- Staffing

- Directing

- Controlling

- Reporting

- Budgeting

\section{Purchasing methods}

- Skillful \& hard poised negotiations

- Effective purchase system

- Should be simple

- Must not increase other Costs

\section{References}

[1].Abdul-Rahman,. H. and Alidrisyi, M. N. (1994) "A Perspective of Material Management Practices in a Fast Developing Economy; the case of Malaysia". Construction Management and Economics, 12, 412-422.

[2].Aibinu A.A and Jagboro G.O (2002): "The Effects of Construction Delays on Projects Delivery in Nigeria Construction Industry”. International Journal of Project Management, 20, 593-599.

[3].Al-Jibouri, S. (2002): "Effects of Resource Management Techniques on Projects Schedules". International

[4].Assaf, S.A., Al-Khalil, M. and Al-Hazmi M. (1995): “Causes of Delay in Large Building Construction Projects". Journal of Management in Engineering March/April.

[5].Choudhury, I. and Phatak, O. (2004): “Correlates of time Overrun in Commercial Construction”. ASC Proceedings of the $40^{\text {th }}$ Annual Conference. Brigham Young University, Provo, Utah, April 8- 10.

[6].Hafez, N (2001): "Residential Projects Obstacles and problems in Kuwait MS Project", Department of Civil Engineering, Kuwait University.

[7].Henesy, M. (1993): “Tools of Total Quality Management”. Journal of Construction Engineering and Management ASCE. Pg 9(4), 329-339

[8].Illingworth, J. and Thain, K. (1998): “Material Management is it Worth It?” Technical Information Service, The Chartered Institute of Building ASCOT. 93, 1-5

[9].Kaming, P.F, Olomolaiye, P. O., Holt, G.O. and Harris F.C. (1997): “Factors Influencing Construction Time and Cost Overruns on High-Rise Project in Indonesia”. Construction Management and Economics, 15, 83-94

[10]. Koushki, P.A and Kartan, N. (2004): “Impact of Construction Materials on Project Time and Cost in Kuwait, 11 (2), 123-132.

[11]. Kraiem, Z.M and Dickman, J.E (1987): “Concurrent Delays in Construction Projects”. Journal of Construction Engineering and Management, 113 (4), $691-602$

[12]. Kwik.K.G. (1994): “Cement and Its Problem in Indonesia”. Kompas October. 10

[13]. Manavazhi, M.R and Adhikari, D.K (2002): "Material and Equipment Procurement Delays in Highway Projects in Nepal'. International Journal of Project Management, Pg 20, 627-632 